\title{
A Review of a Half Century Hybrid Maize Breeding Experiences with Combined Tolerance to Major Biotic and Abiotic Stresses in China and Other Developing Countries
}

\author{
Soon-Kwon Kim ${ }^{1,2,3}$ \\ ${ }^{1}$ Handong Global University (HGU), South Korea \\ ${ }^{2}$ International Corn Foundation (ICF), South Korea \\ ${ }^{3}$ Corn Seed Co. in South Korea and China
}

Copyright $\bigcirc 2017$ by authors, all rights reserved. Authors agree that this article remains permanently open access under the terms of the Creative Commons Attribution License 4.0 International License

\begin{abstract}
Genetic vulnerabilities (GV) of maize (Zea mays L.) have been experienced for a half century globally. Research on quantitative gene resistance (here called "co-survival tolerance") against GV have been studied on Puccinia sorghi common rust, Exserohilum turicum northern corn leaf blight, Bipolaris maydis Southern corn leaf blight, maize streak virus, parasitic witchweed Striga species, Puccinia polysora tropical rust, Peronosclerspora sorghi downy mildew and Ustilago maydis smut. Among the above GE experiences, the most striking experience was parasitic witchweed Striga hermonthica, S. asiatica and S. aspera species in Africa. Without co-survival tolerance, Striga problems in Africa may not be solved in next few decades. The tolerance is controlled by quantitative gene. African origin parasite problems are causing damage of Africa's food crops in 7 billion US dollars annually. Parasites and hosts must be live together and co-survive in nature. The author's experiences of GV with maize in China have been two popular hybrids; Jeungdan 958 and Seunok 335. The former hybrid was covered over 10 million ha during the period of 2007-2013. Its genetic vulnerability due to too wide areas of cultivation of a single hybrid was occurred by corn borers and smut. While Seunok 335 and its sister hybrids now cover majority of maize cultivation of North Eastern (NE) region of China. Seunok 335 has severe root lodging problem under storm. The author observed the lodging in the north of Shenyang, Liaoning Province in 2008, followed in the NE provinces. In addition, it was attacked by E. turcicum in the western region of Jilin Province. Both USA and China have a quarter of the world maize cultivation, each 35 million ha and produce average yield of 10.5 and $6.5 \mathrm{t} / \mathrm{ha}$, respectively. To increase maize production for feed, food and industries as well as to reduce climate changes, China's maize cultivation and breeding must be focused on diverse hybrid
\end{abstract}

development and machine harvest. The later returns stalk and leave to soil. Copies of super hybrids e.g. Seunok 335 by other companies must be discouraged. Under climate changes, breeding stable hybrids with tolerance controlled by QTL must be encouraged. Tolerance breeding has clear advantage from GMO because it shall provide a buffering effect minimizing mutation of aggressive genes. Under the climate changes, the tolerance breeding confers buffering effects of host stability. The author has bred hybrids with tolerance against major biotic and abiotic stresses. Target traits are normal field, sticky, sweet maize, bio energy maize with genes of $b m 3+$ high sugar + leafy, and black herb maize.

Keywords Co-survival Tolerance, Genetic Vulnerability, Maize, Striga, Hybrid, Bio Energy Maize, Quantitatively Inherited Genes

\section{Introduction}

Drs. James L. Brewbaker at the University of Hawaii and Author L. Hooker at the University of Illinois were two supervisors of the author's master and doctoral courses in US during 1971-'74 (Kim [1]). The author had bred of single cross (SX) hybrid maize in the Republic of Korea (ROK) (called here as South Korea) in 1976. It was the first success of SX hybrid maize breeding in Asia (Kim et al. [2], Kim and Brewbaker [3], Kim [4]). Since 1977, the author has advised of hybrid maize development to India, China, Thailand, and Indonesia. The teams of Thailand and CIMMYT were very against the hybrid maize technology during 1970s to the mid of 1980s (Kim [3]). 
The author joined International Institute of Tropical Agriculture (IITA) in Nigeria in 1979. The first priority research work was to breed open-pollinated variety (OPV) followed of hybrid maize with combined tolerance to maize streak virus (MSV) and other major biotic (Bipolaris maydis, Puccinia polysora, African stem borers: Sesamia calamistis, Eldana saccharina, and Busseola fusca, and abiotic (drought, nitrogen deficiency) stresses. MSV was considered as the "No. 1 enemy of maize production" in the countries of sub-Saharan Africa. In 1982, the IITA maize team bred two streak resistant (SR) OPVs (TZSR-W-1, TZSR-Y-1) and multiplied 120 tons of seeds. The team distributed of SR maize to 23 countries. IITA received the King Baudouin Award of CGIAR in 1986 (Efron et al. [5]). In 1983, the author's team succeeded to breed hybrid maize first time adapted to West Africa with combined tolerance to MSV, blights, rusts, stem borers, and drought. The tolerance is controlled by the quantitative trait loci (QTL). The team discovered of Striga tolerance and resistance (STR) maize at Mokwa Station of Niger State of Nigeria in 1983. It was the first discovery of maize tolerance to Striga globally (Kim [6]).

Delegations of Thailand and China visited IITA in 1984 and 1985, respectively. Thailand team members were national and private seed companies in Bangkok, while China team was led by the Vice President of the Chinese Academy of Agricultural Sciences (CAAS) in Beijing. The CAAS asked IITA Director General (DG) to send S. K. Kim to China to review and advice on China's maize breeding in 1986. With 200 public inbred lines, the author visited Beijing (Kim [7]), Nanjing (Kim [8]) and Kwangzhou (Kim [9]). He gave seminars on single cross hybrid maize breeding.

The main type of hybrid maize in China was Mo17 x local collections. A tiny insect mite was serious on Mo17. The author asked Chinese breeders to diversify germplasm sources. During the time, Mo17 x B73 was the dominated single cross maize hybrid in USA.

China's maize cultivation and breeding have been greatly improved for the last two decades. China is the second largest maize cultivation country in the world (35million ha, similar to USA). Average maize grain yield of China is approximately $5.5 \mathrm{t} / \mathrm{ha}$ that accounts for $65 \%$ of USA.

Main causes of the low yield in China would be lacks of machine harvest (not return stalk and leave to soil) and of stable hybrid development and cultivation according to $\mathrm{G} x \mathrm{E}$ ecologies (Kim [10]). The key objective of this paper is to review of the author's ten-year hybrid maize breeding commercially in the NE region of China.

\section{Genetic Vulnerability (GV) Experiences of Maize and Other Crops in Korea}

1. The first GV experience was the collapse of a double cross corn hybrid, "Bokkyo 2" in South Korea in
1970. A new race "A" of Exserohilum turticum was mutated and the hybrid became highly susceptible.

2. USA had a great experience of Texas male sterile (Tms) gene for hybrid corn seed production. The author studied MS and $\mathrm{Ph}$. D courses at the University of Hawaii (UH) under East-West Center Scholarship program. Supervisor was James L. Brewbaker, a kwon geneticist, the author of the "Agriculture Genetics", a popular text book in many universities globally. The author studied one semester at University of Illinois (UI), Champaign \& Urbana under Arthur L. Hooker, the known plant pathologist and geneticist; chairman of the GV Committee of USDA to resolve problem of Tms gene link with Helminthosporium maydis race $T$ (now Bipolaris maydis).

3. The author's thesis research works under Drs. Brewbaker (UH) and Hooker (UI) were common rust caused by Puccinia sorghi Schw. Genetic studies of $P$. sorghi resistance with 22 race- specific different genes including Rpld were carried out by weekly plantings at the Waimanalo Research Farm of UH near Honolulu. Among the 22 race specific genes, 20 were broken down during three-year studies.

4. The title of the Ph. D thesis was "Quantitative genetics of Puccinia sorghi resistance and husk number of Zea mays L.” (Kim [1]). The author became a firm believer on the efficacy of polygenic resistance, inherited quantitatively. Since then, breeding strategy has been, not select a clean, single gene of high resistance. Breeding Korea adapted SX hybrids focused on "tolerance" with some infection of pests to host plant at the early stage of plant development. Host tolerability develops gradually during plant growth. While the high resistance was formed with hypersensitive reactions (Kim [1]). Breeders often confuse the high resistance with escape due to the lack of lesion development.

5. IR8, IR34 and Korean's Tongil Rice stories: The author returned to with Ph.D. of USA, salary $\$ 48 /$ month in 1974 . South Korea promoted a super high yielding Tongil (means unification) rice on $0.8 \mathrm{~m}$ ha of rice cultivation (total, $1.2 \mathrm{~m} \mathrm{ha}$ ) targeting rice self-sufficiency (Kim [11]). Three rice cultivars; "Tongil", "Nopyong" and "Raekyung" were very popular with high resistance gene of rice blast caused by Pyricularia oryzae. In 1974, during the return seminar of the oversea training from the USA, the author predicted the high resistance gene of "Tongil" and its related cultivars be broken down in five-year (Kim [11]). Directional selection with high press of the blast pathogen was too high. Mutation occurred in three years. During of 1977-'78, South Korea rice crop was a total collapse. Only Prof. Hoo-Sup Jung of Seoul National University and a few Japanese scientists agreed of Kim's prediction of the break 
down. Two world known IRRI rice breeders, Drs Beachell and Horfmann told IR8 and Tongil conferred a long lasting high resistance. They argued the author's view was wrong and an impossible theory scientifically.

6. Maize hybrids bred by the author team have conferred durability of approximately three decades. The first example was "Suweon 19" (Kim et al. [12]) that had been cultivated for 34-yr in South Korea (1977-2010) and it is still popularly grown in North Korea (NK). It saved millions of the North Koreans and made seed revolution in NK (Kim [19, 20]). The hybrid is tolerant to E. turcicum, U. maydis, European corn borer and drought. The amount of hybrid seed production was three times higher than the best NK "Hwaseung No. 1" hybrid. "Kim's male inter-planting" hybrid corn seed production technology sowed the pollen parent in-between of every two seed parent rows. This increased numbers of hybrid corn seeds 33\%. For hybrid, number of seeds per ear and per unit area is important.

7. Other durable hybrids that the author's team bred are "Oba Super 1" (white grain) and "Oba Super 2" (yellow grain) at IITA in Nigeria, 1983 and 1984 (Kim 13), respectively. They are still grown popularly in West Africa including Nigeria and Cameroon for over 30-yr. They confer tolerance to MSV, Striga hermonthica, S. asiatica, Bipolaris maydis, ear rot, stem borers and drought. Oba means the King of the Hawoosa dialect of Nigeria. The name of Oba hybrids was put by US Hi-Bred Pioneer International.

The "co-survival tolerance" is one of the most important traits for stability and durability of the crop cultivars. The tolerance genes can be evolved in outside center of the origin (Kim [14]). The author found Striga tolerance (more yield under similar level of infection) and resistance (less number of Striga plants of the infection) genes from US Corn Belt inbreds (Kim $[15,16])$. Crops must have tolerability against biotic and environmental stresses that can guarantee sustainable crop health.

The center of the origin of the most parasitic witchweeds is the continent of Africa. Co-survival tolerance gene technology can be sustainable and a permanent solution against the parasite infection. Host tolerability is important. Low tolerance to the few parasitic plants that do attach would be of little value (Kim [6]). Genes for the tolerance and numbers of Striga plants emergence are controlled by different genes (Kim [6], Kim et al. [17]). Plant tolerance with low Striga emergence plus integrated approach of cereal-legume rotation and manure can be a long-lasting way of combating Striga in Africa (Kim [18]).
This is more so under climate changes. Under nature, parasites and hosts must be co-survive and live-together. We must give a room, say $5 \%$ for the parasite survive and natural evolution. Based on the co-survival tolerance principle and theory, the author discusses on corn breeding and cultivation of the world No. 2 corn cultivation country of China (Kim [21]).

\section{Genetic Vulnerability of Two Hbirds in China}

\section{“Jeungdan 958" Story:}

A Chinese scientist told the author in 2010 that Jeungdan 958 was the most widely grown maize hybrid globally including Australia. The author gave a seminar: "Potential genetic vulnerability of corn cultivation in China" at the Jilin Corn Research Center in Gongjuliang of Jilin Province. Problems of Jeungdan 958 were occurred in two weeks. In August, The author travelled from Shenyang to Gongjuliang weekly and noticed the damage of maize tassel by stem borers. During inbreeding of "Jeungdan 958", high susceptibilities of segregating lines against stalk borers, stalk rot and smut were observed by the author (Kim [10,21]).

"Jeungdan 958" covered over 10 million ha of corn cultivation in the North Eastern (NE) region. It showed outstanding performance in just over 5-yr. High grain moisture at harvest and the low shelling percentage were other problems.

\section{"Seunok 335" Story}

When the author started corn breeding of the NE region of China in 2008, "Jeungdan 958" and "Seunok 335" were the two most popular hybrids. However, Dr. Corn Seeds of China's maize breeding nursery in the Northern Shenyang, Chingsoodae, "Seunok 335" was root lodged 95\% (Kim [10]). The author had never seen this kind of badly lodged corn hybrid in his corn breeding experiences of four decades. Without the storm, the performance of "Seunok 335" was very outstanding across three testing locations with high grain quality. Many farmers had a difficult time to buy seeds of the hybrid. Three years ago, "Seunok 335" was infected heavily by Exerohilum turicum in the western region of Jilin Province. In the previous year, the same hybrid caused severe yield loss by lodging in many areas of the NE region. In spite of yield loss, majority of farmers in the NE region wanted to grow "Seunok 335" or its sister hybrids. Performance of a new hybrid, "Ryangok 99" bred from a seed company in Inner Mongolia Province showed erratic performance upon years.

USA and China have grew on $1 / 4$ of corn cultivation areas, approximately 35 million ha each and they produce average grain yields of $10.5 \mathrm{t} / \mathrm{ha}$ and $6.5 \mathrm{t} / \mathrm{ha}$, respectively. 


\section{Suggestions to the Central and Provincial Governments of China to increase national maize yield significantly}

1. Over 3,000 stress tolerant hybrids with high grain quality must be recommended to farmers nation-wide.

2. Recommendation of the ecology specific hybrid breeding by $\mathrm{G} x \mathrm{E}$ must pursue.

3. Government must discourage copy of the other company hybrids.

4. Too uniform hybrids may bring genetic vulnerability. Less uniform and stable hybrids with genetic diversity can increase average maize yield in China.

5. Government regulation of hybrid maize release must be easier than the current system.

6. Amount of certification fees of release of new corn hybrids must be greatly reduced.

7. A total amount of national production increase must be considered. Over 50 million tons of corn grain can be produced additionally.

8. Foreign seed companies must be encouraged to complete with national companies.

9. Bio-energy (ethanol or electricity) production from maize stalks must be greatly encouraged.

10. Breeders do not select a single gene controlled clean, high resistance against biotic stresses. Tolerance gene with $95 \%$ resistance is superior to the $100 \%$ high resistance. The latter shall bring the mutation.

\section{Dr. Corn Seeds of China in Harbin Focus on Breeding of Non-GMO and Stable Super Corn Hybrids}

1. Stable super corn breeding with high tolerance to biotic (smut, E. turcicum, ear and stalk rots, and insects) and abiotic (lodging, drought, cold) stresses, high grain quality, high shelling percentage, and fast drying during maturity.

2. Bio-ethanol and energy corn breeding with super corn $+b m 3+$ high sugar + leafy. The Pohang Steel Company (POSCO) in South Korea, the third largest steel company globally has supported to breed the bio maize. The $b m$ (brown mid rib) maize can feed beef and milk cows for high digestibility, $20 \%$ up.
The author has found a maize line that contains $23 \%$ of sucrose in stalk. High amount of ethanol can be produced without enzyme. Gene action of leafy is not Mendel inheritance.

3. Stable "honey corn" hybrid with $\operatorname{sh} 2$ gene tolerant to major biotic (E. turcicum, smut, ear and stalk rots, and stem borer) and abiotic stresses (cold, lodging, drought) has been bred. The honey corn of Dr. Corn Seeds Co. does not need to spray any chemicals.

4. Stable and early, and high taste sticky corn with thin pericarp and herbal effects has been bred. Ears of the sticky corn can export to South Korea. China exports 300 million ears of sticky corn to South Korea annually.

5. Black and red medicine corn hybrids have being bred to prevent of cancer, diabetes, foot mouth, and A1 Viruses. Gene action of black corn is complicated, not by Mendel inheritance.

\section{Conclusions}

The government of China must target to increase maize production over 50 million tons more than the current years. Breeding must focus on stable, durable and high grain quality hybrid development with tolerance to major biotic (major diseases and insects) and abiotic stresses (root lodging, drought, cold). Genetic diversity is the key to stabilize of maize production in China. Government must support machine harvest and it shall increase soil organic matters that sustain maize production. Government fee policies on testing of company bred hybrids and registration must be greatly reduced. Any corruption for registration shall discourage hybrid corn research and promotion that eventually effect of national corn production increase. Copies of other company hybrids must be stopped. Business environments of hybrid corn breeding and seed corn for all companies including foreign and plant breeders' right with UPOV regulations should be improved and respected. The author sincerely hopes that China can be the second maize exporting country as well as the second maize production country globally. Burning of maize stalk by farmers must be discouraged and it causes micro dust air pollution and also effects on climate change. Bio-ethanol production of corn stalk and leave, not grain and uses must be pursued to reduce $\mathrm{Co} 2$ production. China can use corn be an engine to combat world food, feed problems and climate changes. 


\section{Appendix}

Explain of figures:

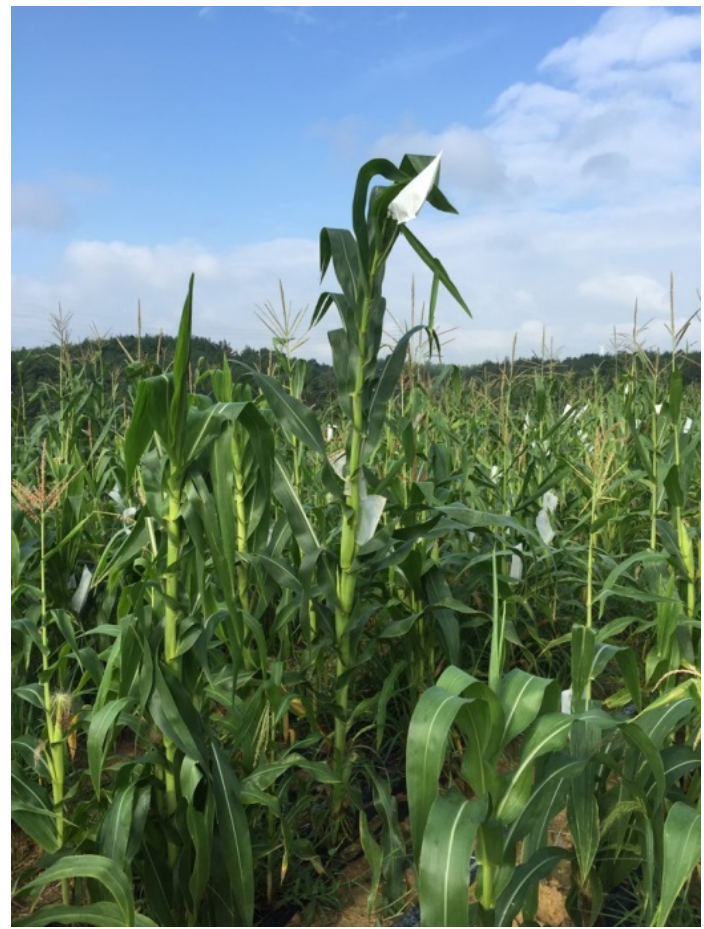

Figure 1. Performance of leafy (LF) gene in Harbin, China, 2015. LF plant has 7 extra leave and $4 \mathrm{~m}$ tall.

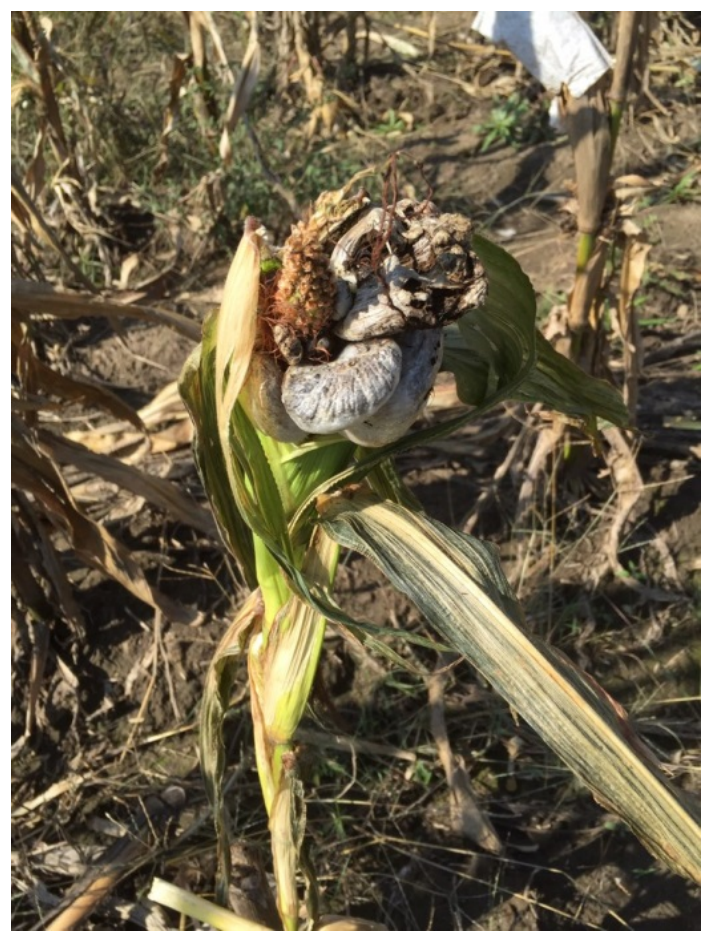

Figure 2. Infection of smut caused by Ustilago maydis in Harbin, China in 2015 .

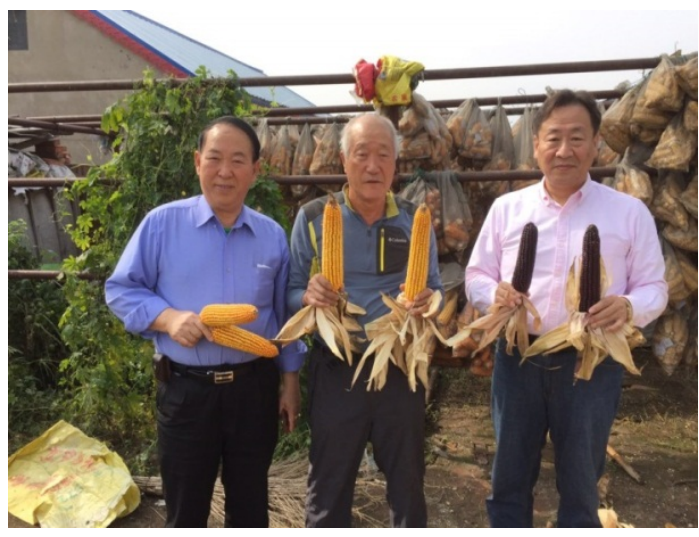

Figure 3. Ear size performance of Seunok 335 (left), new bred hybrid (center) and black corn (right) of Dr. Corn Co. of China, 2016.

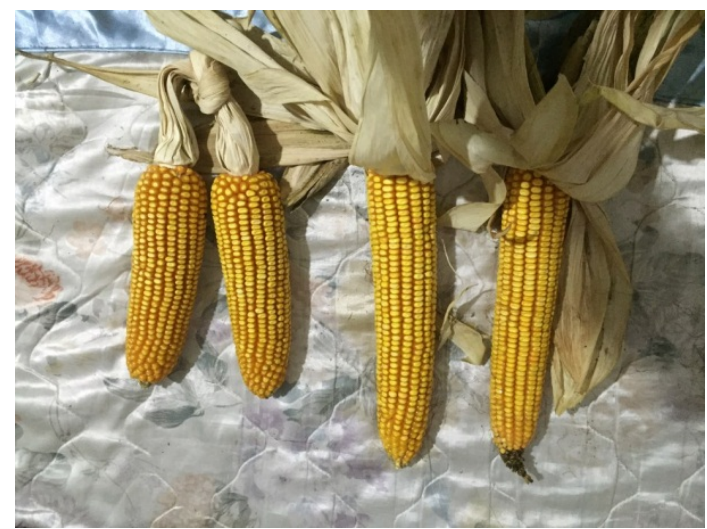

Figure 4. Close up ears of Seunok 335 and Dr. Corn Co. bred in Harbin.

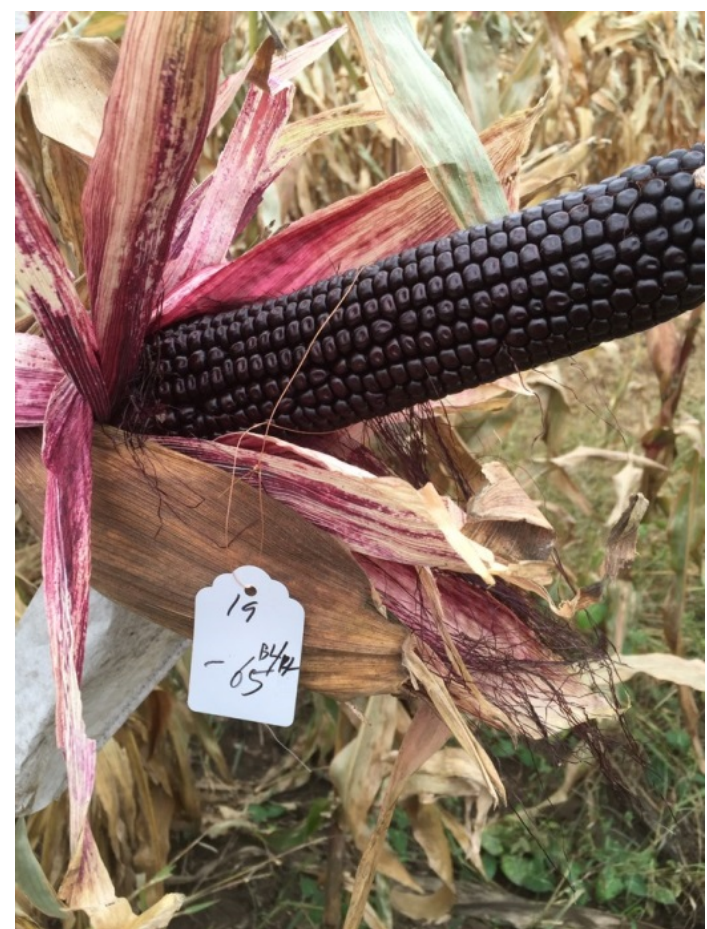

Figure 5. Close up ear of the black corn in Harbin. 


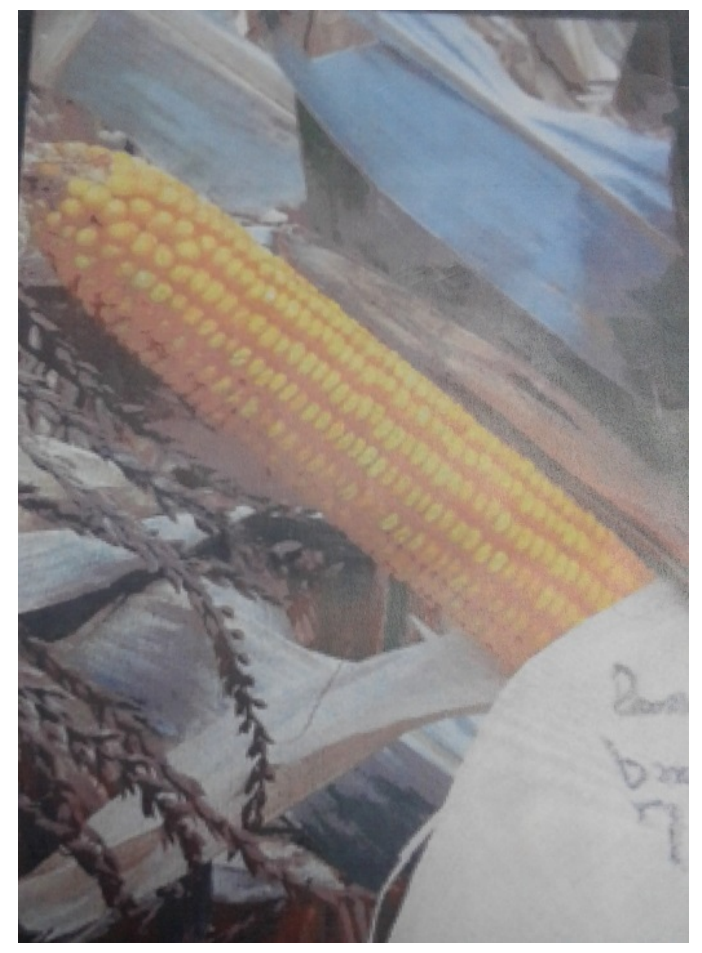

Figure 6. Performance of high yielding $b m 3$ hybrid in Harbin. Usually $b m$ hybrid performs $20 \%$ less yield than the non- $b m$ hybrid.

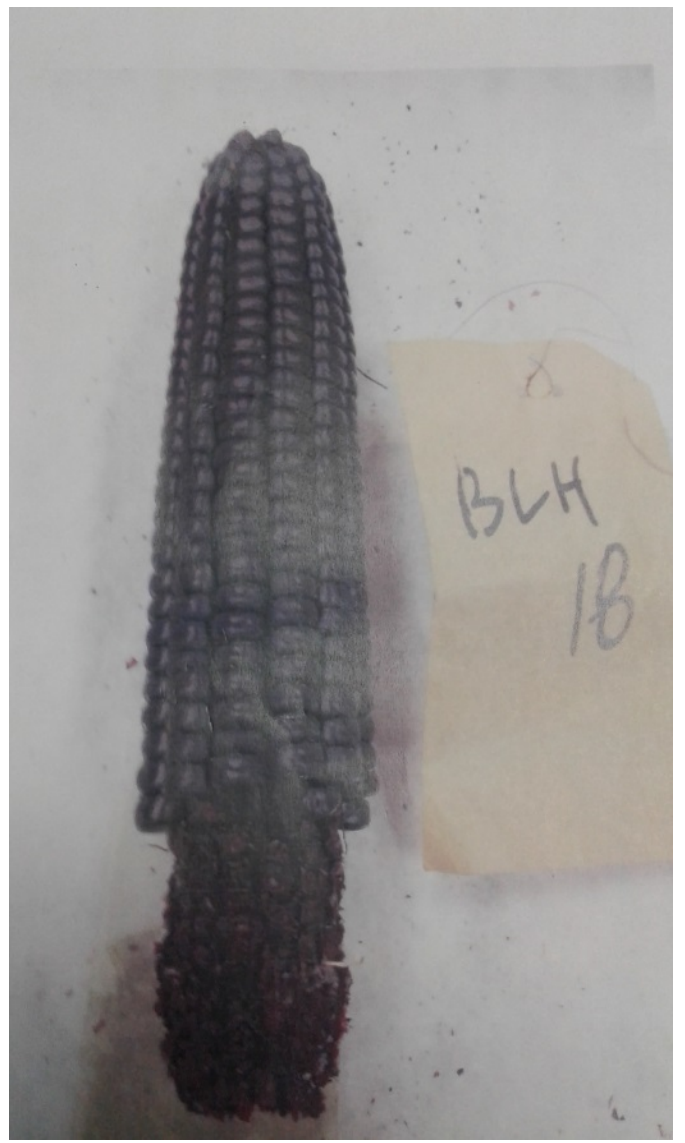

Figure 7. Cob of the black corn that contains high anthocyanin, but kernels and cob were rot at the early stage of breeding.

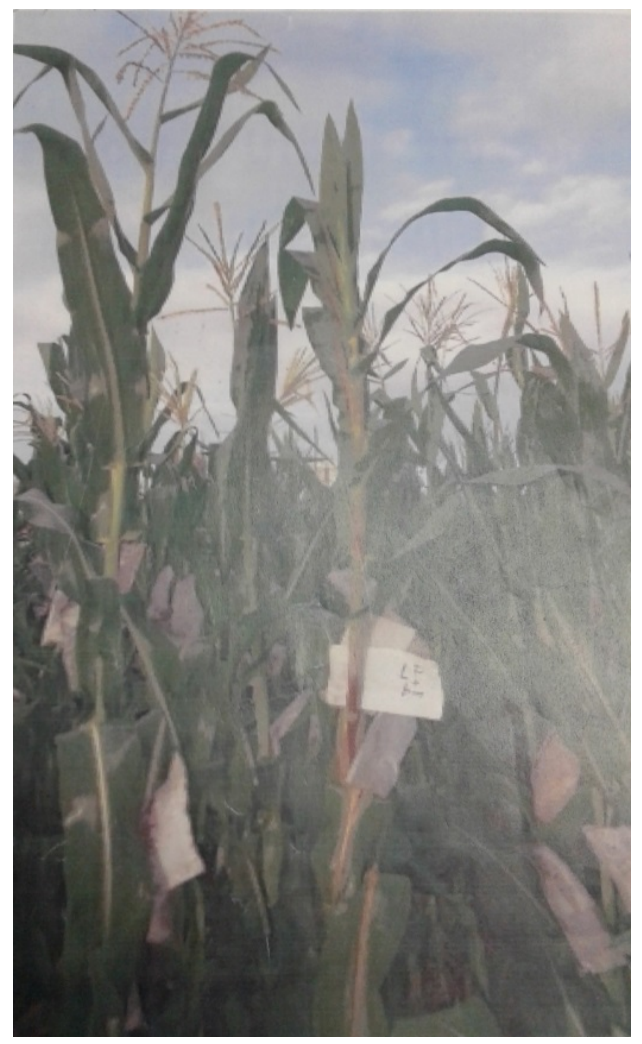

Figure 8. The target of bio corn breeding with $b m+$ leafy + high sugar maize plant.

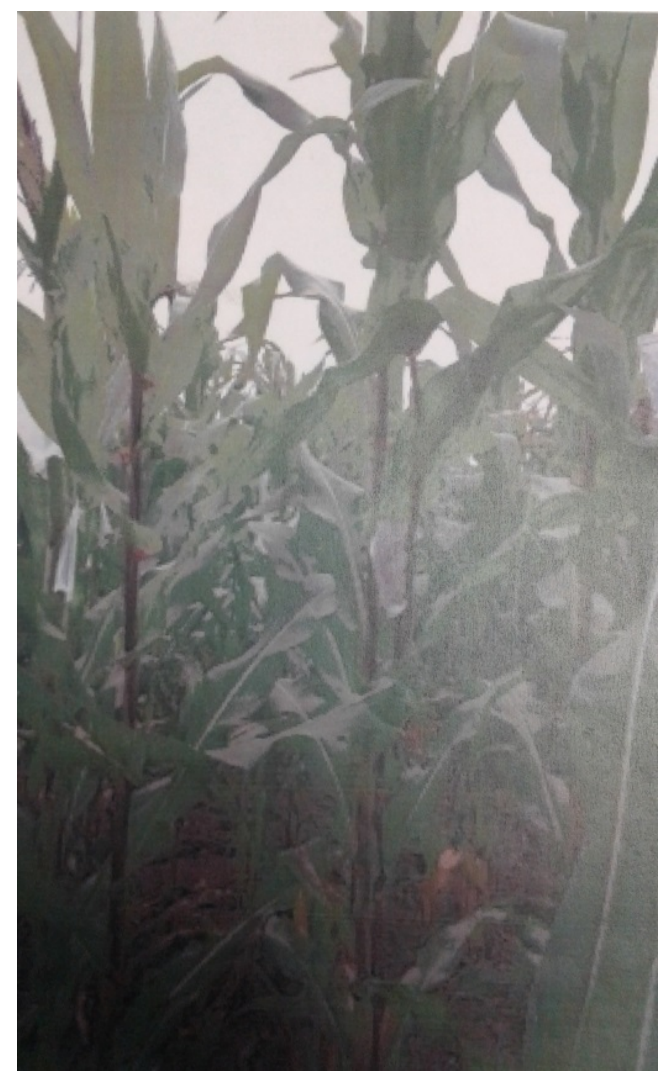

Figure 9. Purple gene of stalk may add into the bio or herbal corn breeding. 


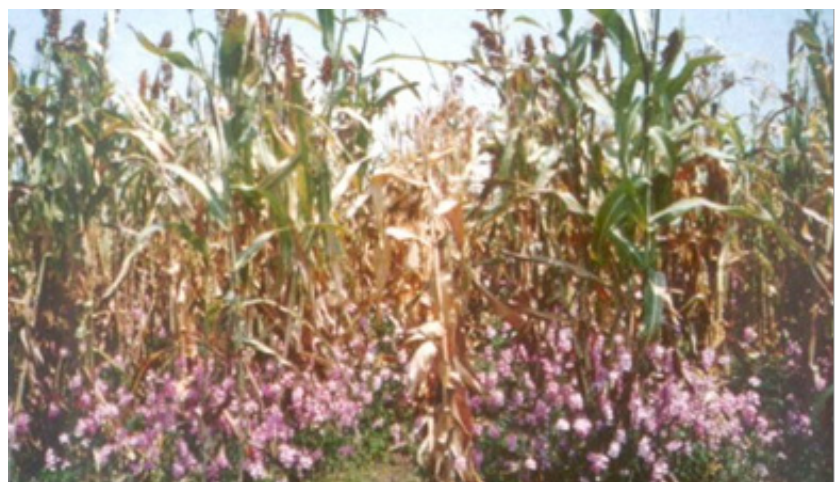

Figure 10. High infection of Striga hermonthica in sorghum and maize in Kisumu of Kenya, 1989.

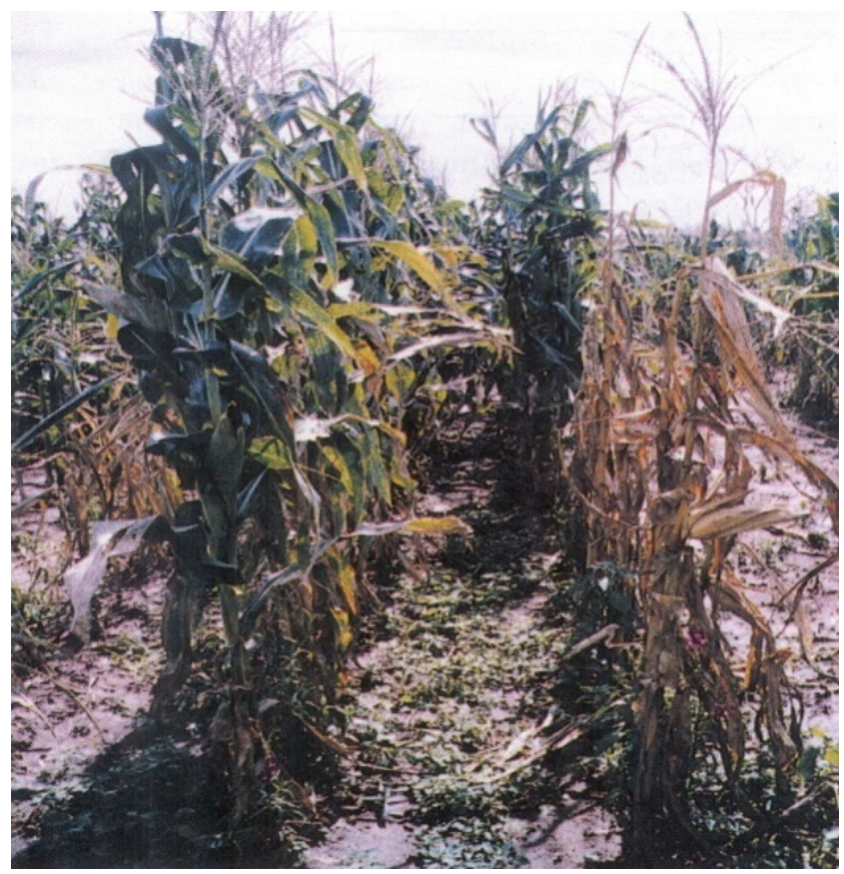

Figure 11. Performance of IITA Striga tolerance and resistance (STR) maize hybrid 8322-13 (front left) compared to a susceptible hybrid 8438-1 (front right) under infection of 20,000 Striga seeds per maize plant inoculation at Mokwa, Nigeria, 1989. The same two hybrids were grown behind without Striga seed inoculation show no damage from the parasite.

\section{REFERENCES}

[1] Kim, S. K. 1974. Quantitative genetics of Puccinia sorghi resistance and husk number in Zea mays. Ph.D. Thesis. College of Tropical Agriculture and Human Resources, University of Hawaii, Honolulu, Hawaii 96822. p.188.

[2] Kim, S. K., Y. S. Ham, K. Y. Park, S. U. Park, H. G. Moon, H. O. Choi, and J. L. Brewbaker. 1978. A disease, insect, and lodging resistance super high yielding maize hybrid, "Suweon 19". The Research Report of the Office of Rural Development (ORD) Publication. Crop 20: 149-156, Suweon, Korea.

[3] Kim, S. K. and J. L. Brewbaker. 1979. Maize green revolution in Korea. The American Society of Agronomy Abstracts. Fort
Collins, Colorado. p.80.

[4] Kim, S. K. 1979. Evaluation of the effectiveness of high yielding maize hybrids disseminated to small Korean farms and estimation farm income increase and rural farming technology improvement. UN-ESCAP Contract Report by the Office of Rural Development (ORD). New name is the Rural Development Administration (RDA), South Korea: pp.74.

[5] Efron, Y., S. K. Kim, J. M. Fajemisin, J. H. Mareck, C. Y. Tang, Z. T. Dabrowski, H. W. Rossel, G. Thottappilly and I. W. Buddenhagen. 1989. Breeding maize for resistance to maize streak virus: a multidisciplinary team approach. Plant Breeding 103: 1-36.

[6] Kim, S. K. 1994. Genetics of maize tolerance of Striga hermonthica. Crop Science 34: 900-907.

[7] Kim, S. K., 1986. Progress of hybrid maize project at IITA. The Chinese Academy of Agricultural Sciences (CAAS) in Beijing, China, August, 14.

[8] Kim, S. K., 1986. Hybrid maize development for Africa. The Jiangsu Academy of Agricultural Sciences, Nanjing, of the CAAS, Nanjing, China. August, 17.

[9] Kim, S. K., 1986. IITA Maize research program for Africa. The Guangdong Academy of Agricultural Sciences of the CAAS, Guangzhou, China, August, 20.

[10] Kim, S. K. 2014. Six-year of genetic vulnerability of hybrid corn breeding in China, the $56^{\text {th }}$ US Annual Maize Genetic Conference hold in Beijing, March 13-16.

[11] Kim, S. K. 1976. Problems of genetic vulnerability in crops. Korean J. Breeding Vol.8: 83-90.

[12] Kim, Soon-Kwon, Dongho Kang, and Gahee Moon. 2010. Three most outstanding contributions of the Rural Development Administration (RDA) of South Korea would be rice self-sufficiency through Tongil rice, single cross hybrid corn technology and Greenhouse facility promotion. The Spring Annual Meeting of Korea Crop Science Society, Daejeon, Korea. Poster No.PB-38, p.92.

[13] Kim, S. K. 1987. Breeding for hybrid varieties of maize. W.P. Feistritzer and A.F. Kelly, (Ed.) p. 55-81. Hybrid Seed Production of Selected Cereal, Oil and Vegetable Crops. FAO Plant Production and Protection. 82, The Workshop was hold in Surabaya, Indonesia.

[14] Kim, S. K., J. L. Brewbaker, N. M. Yoon, H. J. Kim, and N. Claudino. 2008. Co-survival tolerance principle can be the best option to breed crops against environment changes (Abstract). p.97, the $5^{\text {th }}$ International Crop Science Congress. April 13-18, Jeju International Convention Center, Jeju, Korea.

[15] Kim, S. K., R. A. Robinson, K. Atkinson, V. O. Adetimirin, The C. and G. Salle. 1998. (eds.). Combating parasitic weeds through horizontal resistance. Proceedings, International Workshop organized by IARI-KNU/ICF, PASCON-FAO, STRC-OAU, KNACF and KOICA, 27-28 August, 1997, Brussels, Belgium. International Agricultural Research Institute (IARI) of the Kyungpook National University (KNU), Taegu / International Corn Foundation (ICF), Seoul, the Republic of Korea.66pp.

[16] Kim, S. K. 1991. Breeding maize for Striga tolerance and the development of a field infestation technique. p. 96-110. In: S. 
K. Kim (ed.) Combating Strigain Africa. Proc. of the International Workshop on Striga by IITA, ICRISAT and IDRC.

[17] Kim, S. K. 1991 (ed.). Combating Striga in Africa. Proceedings of a Striga Workshop held at the International Institute of Tropical Agriculture (IITA), Ibadan, Nigeria, Aug. 22-24, 1988. IITA/ICRISAT/IDRC. pp. 145.

[18] Kim, Soon-Kwon. 1996. Horizontal resistance: core to a research breakthrough to combat Striga in Africa. Integrated Pest Management Reviews 1: 229-249.
[19] Soon-Kwon Kim, 1999. News Focus, North Korea. Joint projects allow a peak into an impoverished system. Science Vol.285, 10 Sept., p.16, www.science.org.

[20] Soon-Kwon Kim, 2000. Combining national efforts for combating food deficiency: development of super maize. International Project 1. Expo 2000, Hannova, Germany

[21] Soon-Kwon Kim, 2016. A decade experiences of genetic vulnerability of corn cultivation in China and its application of hybrid corn breeding. 3-5 Nov., 2016 BIT International Congress. Hilton Hotel, Shanghai, China. 